\title{
Marco Filoni, Anatomia oblężenia. Strach w mieście [Anatomia di un assedio. La paura nella città], przeł. Joanna Ugniewska, Fundacja Augusta Hrabiego Cieszkowskiego, Warszawa 2020, ss. 210
}

DOI: http://dx.doi.org/10.12775/RF.2021.011

O miastach powiedziano i napisano już wiele. O tym, że zaczęły powstawać (jeśliby zastosować dzisiejsze kryteria miejskości) w epoce brązu, że powstawały ze względu na korzyści i potrzeby swoich czasów (głównie handel i obronność), że osiedlić się w mieście to jakby zyskać nowe życie - wygodne, bezpieczne oraz, co dla wielu nie było mniejszą wartościa, „cywilizowane”, a przez to niekiedy prestiżowe.

Opisy założenia pierwszych ośrodków urbanistycznych pojawiają się w najstarszych zabytkach kultury pisanej. Jeśli wierzyć Księdze Rodzaju, ludzie zaczęli osiedlać się w większych skupiskach dość szybko, niedługo po wygnaniu pierwszych ludzi z raju. Historia miasta zaczyna się od Kaina: „Gdy Kain zbudował miasto, nazwał je imieniem swego syna: Henoch" (Rdz 4,17). Fakt ten często umyka tym, którzy interesują się kulturowymi początkami miasta. Wszak zakłada je bratobójca i to wbrew boskiemu nakazowi: „tułaczem i zbiegiem będziesz na ziemi".

Tak rozumiane miasto staje się zaprzeczeniem raju czy ogrodu - skoro karą Boga za zabójstwo Abla ma być wieczny nieurodzaj uprawianej przez Kaina ziemi, decyduje się on na kolejny akt nieposłuszeństwa zamiast zgodnie z wolą Stwórcy wieść życie pielgrzyma, ten wznosi pierwsze mury. Miasto wyrasta na przekór niebu, a zamieszkujący je człowiek, obserwując miejski zgiełk i chaos, jakby podskórnie przeczuwa, że w mieście jest tak naprawdę zbiegiem szukającym schronienia. Daremnie.

Książka Anatomia oblężenia. Strach w mieście nie tyle zrywa z przekonaniem, że miasto może być miejscem harmonii i ostoją spokoju wobec zewnętrznych zagrożeń, ile wskazuje na pewną ambiwalencję, która leży u źródła powstania miasta: ono nie tylko daje schronienie i poczucie bezpieczeństwa, ale również samo w sobie może być miejscem strachu i dyskomfortu. Teza to może nieoryginalna i nader oczywista, skoro już 
od czasów Thomasa Hobbesa wiadomo, że strach pełni konstytutywną rolę władzy politycznej i składnia do tego, by ludzie zrzeszali się we wspólnoty państwowe, a także miejskie: umowa społeczna, owszem, usuwa lęk przed tym, co stanowiło zagrożenie w stanie naturalnym, ale nie usuwa obawy przed władcą. Strach zamieszka zatem na placu przed ratuszem oraz na pałacowym dziedzińcu. Stanie się gwarantem politycznego porządku, po który władza będzie mogła sięgać w dogodnej chwili.

Książka Filoniego jest zatem zarówno książką o mieście, jak i książką o strachu. A mówiąc jeszcze precyzyjniej, traktuje o tym, które aspekty życia $\mathrm{w}$ mieście ten strach generowały i jak próbowano (lub nadal się próbuje) ów strach oswoić. Pisze bowiem Filoni we wstępie: „Żywimy nadzieję, że zostawimy go [strach - D.W.] za bramą miasta, za drzwiami naszego domu. Następnie jednak odkrywamy, że znajdzie on zawsze sposób, by przeniknąć do wewnątrz. Jak gdyby na tym właśnie polegało przekleństwo naszych miast. Od chwili, gdy ludzie zaczęli budować domy, miasta, wymyślono opowieści, do których można się odwołać. Każda z nich ma na celu uwolnienie od strachu, demontaż jego mechanizmów, trzymanie go na odległość" (s. 15). Tytułowa "anatomia oblężenia" dotyczy zatem konstruowania pewnej narracji o tym, w jaki sposób miasto „oblęża” mieszkańców, którzy szukają w nim schronienia. A czyni to zarówno od środka, jak i na zewnątrz.

Książka opublikowana nakładem Fundacji Augusta Hrabiego Cieszkowskiego ukazała się jako kolejna pozycja z dość różnorodnej tematycznie serii Miniatury Filozoficzne. I w istocie - jako praca objętościowo niewielka - sama jest swego rodzaju miniaturą filozoficzną. Interesująca jest już sama konstrukcja książki, którą po pierwszym rozdziale wprowadzającym oraz odautorskiej nocie wstępnej tworzy "mozaika” filozoficznych esejów, między sobą dość luźno powiązanych tematycznie, choć niewątpliwie mających wspólny mianownik w postaci zagrożeń "czyhających" na mieszkańców miast - tych dawnych oraz tych współczesnych. Właściwie każdy esej składający się na książkę tworzy pewną całostkę, która sama w sobie mogłaby tworzyć krótki szkic na temat wybranego aspektu, analizujący nie do końca oczywisty związek zachodzący między miastem a strachem.

A trzeba przyznać, że autor pomiędzy poszczególnymi wątkami eksponującymi wybrane aspekty strachu w mieście (i poza nim) porusza się bardzo zręcznie, choć niekiedy płynność przejść z jednego wątku do drugiego może nastręczać czytelnikowi problemów ze śledzeniem toku rozumowania Włocha. Zwłaszcza że zwięzła forma eseju, jego otwarty charakter i nielinearny sposób prowadzenia wywodu nie zawsze sprzyjają uchwyceniu konkluzji (jeśli taka jest - bywa bowiem, że Filoni, na postmodernistyczną modłę, raczej prowokuje, niż wyprowadza konkretne wnioski). 
Nie sposób w kilku zdaniach opisać, choćby skrótowo, wszystkich poruszanych przez filozofa kwestii. Dotyczą one bardzo różnorodnej problematyki strachu związanej z miastami różnych kręgów cywilizacyjnych na przestrzeni dziejów, ale też aspektów będących wynikiem swobodnych rozważań autora na temat miast, których powstanie nigdy się nie ziściło: zarówno tych będących idealistycznymi utopiami, jak i dystopiami rodem z najgorszych koszmarów. Już sam spis treści zbudowany na zasadzie listy hasel - jest swoistym wprowadzeniem do tytułowej „anatomii oblężenia”. Prowadzą one poprzez fizyczne i namacalne miejsca czy obiekty jak "mur", niemniej warto w tym miejscu zatrzymać się nad przynajmniej kilkoma, aby przybliżyć nieco strukturę książki oraz najważniejsze treści.

$Z$ racji tego, że głównym zainteresowaniem autora jest filozofia polityki (specjalizuje się on w heglizmie francuskim, zwłaszcza w myśli Alexandra Kojèva), nie powinien dziwić fakt, że dwa pierwsze rozdziały tej niewielkiej monografii skupiają się wokół tytułowego strachu $\mathrm{w}$ relacji z władza, przede wszystkim niedemokratyczną i totalitarna, stając się wodą na młyn dla jej despotycznych zakusów. Pierwszy z rozdzialików, Bloki, otwiera streszczenie antyutopijnej powieści Blokken z 1931 roku pióra holenderskiego pisarza Ferdinanda Bordewijka. Opowieść ta, będąca swoistą wizją urbanistyczną owładniętą ideą geometryzmu, a ściślej mówiąc - kubizmu (fetyszem władzy są czworoboczne surowe budynki oraz równoległe i prostopadłe ulice), służy Filoniemu do rozważań, czym w istocie jest ów ordus geometricus (termin pisany kursywą jest zarazem tytułem kolejnego rozdziału) na służbie władzy nieliczącej się z koncepcjami architektoniczno-urbanistycznymi innymi niż jej własna.

Przestrzeń miejska, jak przekonująco dowodzi włoski filozof w kolejnym rozdziale, nie jest politycznie neutralna, a "antymiasto" przedstawione przez Bordewijka na kartach jego powieści to nie tylko literacka wizja monotonnego oraz przygnębiającego krajobrazu miejskiego, ale zarazem filozoficzny opis pewnego - historia pokazała, że niezupełnie fikcyjnego - społeczeństwa, w którym okrągłość jest wrogiem jednowymiarowego państwa, gdzie kubistyczne kształty symbolizują jedyne dopuszczalne wartości: własność wspólna, stabilność i jednorodność, w odróżnieniu od „wywrotowej” i podkreślającej indywidualizm, wolnościowej wiary w okrąg jako figurę porządkującą przestrzeń.

To przecież - argumentuje Filoni - nie o figury chodzi. Historia miejsc, jak powtarza za Michelem Foucault, jest historią władzy, a idee polityczne, tym razem Filoni powołuje się na Carla Schmitta, nie mogą istnieć bez fizycznej przestrzeni. Nie od dziś wiadomo, że architektura może uczyć obywatela szacunku do władzy, porażać go swoim przepychem albo - i ten wątek bardziej akcentuje włoski filozof - budzić w nim strach, co jest pożywką dla władzy totalitarnej. 
Filoni w przenikliwy i niepozbawiony erudycji sposób zauważa związki znaczeniowe między wytworami kultury materialnej i duchowej starożytności a dziedzictwem czasów współczesnych. Nawet mur (i tak zatytułowany jest jeden z kolejnych rozdziałów) jest dla niego przestrzenią symboliczna, która w różnych epokach znajduje odmienne artykulacje. „Mur - pisze Włoch - wyznacza granicę. Poza wyznaczaniem przestrzeni wskazuje na aktywny rozdział, rysuje linie, oddziela to, co na zewnątrz, od tego, co w środku. Nie wydaje się, by był produktem szczególnie wyrafinowanej techniki, a jednak spełnia znakomicie swoją rolę. Jest prosty" (s. 40).

I mogłoby się wydawać, że słowa te zapowiadają nie raz już powielony banał, jednak okazują się prowadzić do wcale nieoczywistych refleksji. Mur to akt założycielski - „bez muru nie ma domu” (s. 40). Wiek XX zna inne mury, także dzielące, choć pozwalające spojrzeniu dojrzeć, co jest za nimi. Ta specyficzna technika kontroli przestrzeni zostanie wykorzystana w obozie, swoistym anty-mieście, kolejnym przerażającym wynalazku ubiegłego stulecia, będącym po Agambenowsku etymologicznym „wyjątkiem" - czymś „wyjętym, włączonym poprzez własne wyłączenie" (s. 42).

Dalsza część tej niewielkiej monografii meandruje w rozliczne wątki na temat symbolicznej struktury miasta zbudowanej na zasadzie antynomii wnętrze-zewnętrze, a także poddaje filozoficznemu namysłowi realne zagrożenia, którym miasto musiało stawić wyzwanie, takie jak zaraza czy oblężenie przez wrogą armię. Nie brakuje tu odniesień do utopii, ale chyba największym, nieodżałowanym paradygmatem miasta idealnego jest dla Filoniego grecka polis. Do niej Włoch, jak się zdaje, czyni najwięcej nawiązań.

Miasto włoskiego filozofa to teatralna scena, na której strach odgrywa główną rolę. Filozof daleki jest jednak od kontestowania ośrodków miejskich jako dorobku cywilizacji materialnej czy po prostu miejsca do osiedlania się. W mieście panował i zawsze panować będzie strach, ale nie można na dobre go opuścić. „Możemy - zapewnia Filoni - zbudować jak najbezpieczniejsze aglomeracje (i napełnić je wideokamerami, drutem kolczastym, zaporami...); strach nie pozostanie nigdy na zewnątrz. Zawsze bowiem był i będzie, przenika świat, odkąd pojawił się w nim człowiek. Strach przemierzył całą naszą historię, strach przed innym, choroba, głodem, wrogiem, niewiernymi, tym, co boskie, i tym, co dalekie. Strach przed samym sobą" (s. 160).

Odpowiedź na wyzwanie, które stawia tytuł monografii: Anatomia oblężenia. Strach w mieście, może nieco zaskakiwać, zważywszy na fakt, że monografia nie stanowi nic innego, jak właśnie wielokontekstowe studium obecności strachu w mieście. Skoro strachu nie da się całkowicie wyzbyć, a miasto wydaje się z nim istotowo złączone - jak przewrotnie pyta filozof - to czy nie lepiej jest przyjąć strach i uznać go za część 
naszej ludzkiej, kainowej tożsamości byłego nomady, która buntowniczo skłoniła nas do wykopania pierwszych fundamentów pod pierwsze, stałe schronienie?

Dawid Winctaw Uniwersytet Mikołaja Kopernika, Toruń ORCID: 0000-0002-0738-4057 e-mail:dwinclaw@doktorant.umk.pl 